\title{
The Carrying Capacity of Infrastructure and Spatial Planning to the Recovery of Pandan Beach Natural Tourism Due to the Covid-19 Pandemic in North Sumatra (Central Tapanuli Regency Case Study)
}

\author{
Fernando Raja Partogi Sibagariang ${ }^{1}$, Agus Purwoko \\ ${ }^{1,2}$ University of Sumatera, Indonesia \\ fernando.sibagariang@yahoo.com
}

\begin{abstract}
The purpose of this research is: (1) know the carrying capacity of infrastructure for the recovery and development of natural attractions on the pandan beach of Central Tapanuli Regency, (2) analyze the suitability of spatial arrangements in the Regency towards the recovery and development of natural attractions on pandan beaches of Central Tapanuli Regency, (3) analyze the priority of handling infrastructure and spatial arrangement policies for the acceleration of recovery and development of natural attractions on pandan beaches. Central Tapanuli. The research method used is to use descriptive qualitative methods with case study models. Data collection techniques with interviews and documentation. The results of this study, that is (1) The carrying capacity of central Tapanuli Regency infrastructure to the recovery and development of natural attractions on pandan beach, already has infrastructure such as transportation, economy, health and social. (2) The suitability of spatial arrangements in the Regency to the recovery and development of natural attractions on pandan beach, namely when viewed from the distribution of facilities and infrastructure and the distribution of tourism attractions the most influential space functions due to the covid-19 pandemic are restaurants or restaurants and lodgings or hotels. (3) Priority of handling infrastructure and spatial arrangement policy for the acceleration of recovery and development of natural attractions on pandan beaches of Central Tapanuli Regency, namely the economy. Whether it's a small or medium-sized business or a large scale.
\end{abstract}

Keywords

infrastructure; spatial; Pandan beach recovery

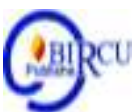

\section{Introduction}

The carrying capacity of infrastructure on pandan beach is one of the basic concepts developed for the sustainable utilization of natural and territorial resource services based on the ability of natural resources themselves. This concept was developed with the aim to look at infrastructure in terms of transportation, economic activities, health facilities, social activities, and educational facilities to recover from the impact of the covid-19 pandemic and the development of pandan beaches. Not only infrastructure, spatial carrying capacity is also one aspect that can be used as a weapon against the recovery of pandan beach attractions. Spatial conformity both from the structure and function of space can help the recovery and development of pandan beaches due to the covid-19 pandemic.

Tourism development planning should pay attention to the carrying capacity based on tourism goals. Tourism facilities are also a factor in determining carrying capacity, such 
as roads and resting places. In addition, it is also important to look in terms of the ability of the environment and region to support the means. Tourism development that does not pay attention to the carrying capacity of the environment will reduce the quality of the environment and damage to the ecosystem used for tourism, so that it will eventually inhibit and even stop the development of tourism.

Infrastructure should support comfort and service for tourists in pandan beach natural tourism areas. In addition, the development of tourist attractions into marine tourism areas must also be supported by the priority of appropriate infrastructure development. Law No. 10 of 2009 on Tourism states that tourism development is carried out based on the master plan of national tourism development, Province and Regency / City, which is an integral part of national long-term development (article 8 paragraph (1) and (2)). The Tourism Development Master Plan is regulated in government regulations or provincial / regency / city regulations. Article 8 of Law No. 10 of 2009 on Tourism and Government Regulation No. 50 of 2011 needs to be planned in order to meet development goals and objectives. Tourism development is clearly part of national development that is intact and not limited to physical development only.

\section{Review of Literature}

\subsection{Tourism}

Tourism is an activity that is done either group or individual to a certain area in search of excitement. Both tourism is a system that attracts the heart and takes care of tourists and other visitors with a combination of symptoms and cholera of tourists, businesses, local governments, local communities. Tourism is complexly integrated in the economic, social, and cultural fields (Sukma, 2017). The shift of people in a short period of time to areas outside of work and life and activities during settling in the destination is also called tourism. Tourist activities can be continued if they meet certain conditions, namely:

1) Ecologically it will continue if there is no adverse impact on the local ecosystem. The process of export, maintaining natural resources and the environment from negative impacts can be done conservation or preservation.

2) Socially acceptable, the expertise of the local community in absorbing tourism activities without inviting social opposition.

3) Culturally acceptable, the local community can adjust to a fairly different tourist culture.

4) Economically commercial, the profits generated can prosper the local community.

The advantage of the tourism sector lies in its ability to increase foreign exchange and to drive various other business sectors such as the home industry. Thus, developed countries and developing countries continue to develop and improve the quality of their country's tourism. (Amin et al, 2019).

\subsection{Beach Tourism}

The tourist area with the main attraction is beach recreation with tourists visiting the beach. Many activities that can be done by tourists when traveling generally have fun on the beach, play water or swim, satisfy themselves in beautiful and free natural conditions such as when drowning and rising the sun. The parameters used there are 10 with 4 classification ratings to adjust beach tourism into the category of recreation. Beach tourism must be adjusted to the parameters, namely, the distance of the surface to the bottom of the water, the type of beach, the area of the beach, the area of the water, the area of the water, 
the area of the water, the water base, the speed of the current, the slope of the beach, the closure of the beach area, dangerous animals and freshwater readiness (Suniastha, 2018).

\subsection{Infrastructure}

Tourism infrastructure development must be designed in an integrated manner both structuring the area, roads, provision of raw water and clean water, waste management, sanitation, and improvement of population occupancy. The master plan and layout must be well programmed. A good tourism infrastructure will encourage new sources of growth and boost the region's economic growth. In addition, adequate road infrastructure will strengthen connectivity between growth nodes in industrial and tourism areas. All of that will certainly cause a very large multiplier effect. We are optimistic that the main economic sector that will quickly rise is the tourism sector.

When the Covid pandemic is resolved with the number of sufferers that continues to decline, the interest of people to travel will increase. People have been saturated and tired for months held hostage by Covid and do not freely travel. It can also be seen how each area is competing to evoke new recreation centers nuanced nature. New tourist centers such as in North Sumatra, Yogyakarta, and Bali are successful examples of how the location became a new favorite destination. Many investors are busy building village tours that are designed in such a way, accompanied by interesting photo spots. The concept of such tourism becomes an extraordinary allure, supported by rapid advance technology that is also a vehicle for effective promotion (Kunjana, 2020).

\subsection{Spatial Planning}

Jayadinata in Adisasmita (2010) defines space based on aspects of regional geography, namely aspects of general geography, space (space) is the surface of the earth which is a layer of the biosphere, where plants, animals and humans live. Based on regional geography, space is a region that has geographical boundaries, namely limits according to physical, social or governmental conditions that occur from part of the earth's surface and the layers of soil below it and the air above it. Central Tapanuli Regency Regional Regulation No. 8 of 2013 on Central Tapanuli Regency Spatial Plan 2013-2033, Article 2 paragraph (2) "The scope of the planning area is an area with a defined limit based on administrative aspects covering land areas, coastal and marine areas, other waters, and airspace".

According to Nia K. Pontoh \& Iwan Setiawan (2008), the elements forming the structure of urban layout consist of activity centers, functional areas, and road networks. A city or urban area can basically be viewed as a spatial system, which internally has elements that form it and its interconnectedness with each other. The city as a system / spatial system is a structural form and pattern of utilization of space, whether planned or not, which characterizes the area with the main activities not agriculture. The structural form of the utilization of urban space is the elements that form urban areas hierarchically and structurally related to each other to form urban spatial planning. Structural forms of utilization of urban space include the hierarchy of urban activity service centers, such as urban centers, city centers, and environmental centers; supported by road infrastructure systems such as arterial roads, collectors, and local. In addition to urban activity service centers and urban functional areas, the elements forming urban spatial structures are infrastructure and facilities systems. Urban infrastructure is a basic physical completeness that allows urban residential areas to function as they should. 
Types of infrastructure: Transportation, Clean water, wastewater, drainage, sewage, electricity, and telecommunications. Urban facilities are the completeness of urban residential areas, namely: Education, Health, Worship, Government and Public Services, Trade and Industry, and sports facilities and green open spaces.

\section{Research Methods}

The research method used is to use descriptive qualitative methods with case study models. Case studies are one type of descriptive qualitative research. The study focused intensively on a single object. In this case obtained from various data sources, interview results in the field and other sources that are considered knowing (Nawawi, 2003). Data collection techniques with interviews and documentation..

\section{Results and Discussion}

The spread of COVID-19 in North Sumatra Province that has occurred over the past two years is constructing an understanding of the need for post-COVID-19 development recovery planning. This is based on the many negative impacts caused by COVID-19, so policy instruments that accelerate the development recovery process are absolutely necessary. In the context of tourism, COVID-19 followed by the implementation of LargeScale Social Restrictions (PSBB) has implications for the cessation of all tourism activities in Central Tapanuli Regency which has implications for economic losses in the tourism sector.

Central Tapanuli Regency has a land area of 2,194.98 Kilometers 23.06 percent of the area of North Sumatra Province and the sea area of Central Tapanuli Regency $\pm 4,000$ Square Kilometers. Overall the area of Central Tapanuli Regency is $\pm 6,194.98$ square kilometers. Administratively Central Tapanuli Regency has 20 subdistricts, consisting of 159 villages and 56 villages. The most extensive district is Kolang District which is 400.65 $\mathrm{km} 2$ (18.25 percent), while the smallest is Barus District which is $21.81 \mathrm{~km} 2$ (0.99 percent).

\subsection{Infrastructure Carrying Capacity for The Recovery and Development of Natural} Attractions in Pandan Beach, Central Tapanuli Regency

a. Transportation

Pandan Beach is one of the tourist destinations in Pandan District, Central Tapanuli Regency. Pandan Beach with an area of 6 hectares with a beach length of about 2.5 kilometers but the width of white sand at the lowest receding is only about 7 meters. Pandan Beach is a beach tourist destination located in Central Tapanuli Regency that is crowded with tourists. Accessibility in Central Tapanuli Regency there is an airport as an embryo of development and the existence of public transportation that connects Central Tapanuli Regency with other districts or even up to the provincial capital, namely Medan City. In this period, for accessibility to Central Tapanuli Regency there is Ferdinand Lumban Tobing Pinangsori Airport, and public transportation terminal (land) Pansurbatu Terminal and Pandan Bus Terminal. Access to the natural attractions of pandan beach can be reached by air and or by land. 


\section{b. Communication}

Communication is part of accessibility. Accessibility is the ease of achieving a goal, which concerns comfort, security, and travel time. This becomes important to note because the higher accessibility the easier to reach and the higher the comfort level of tourists to come visit. Access to the highway in Central Tapanuli Regency is quite easy because the distance of pandan beach with a large road is only a matter of meters, around 50 meters. This tourist attraction is located on the district road, where the road is the main line so that many are passed by the local community of the district. The condition of the road to pandan beach is considered to be good enough evidenced by a paved road for a long time. In addition to asphalt roads, the impact of technological advances presents a network. This network is used as a means of communication for the community, tourists and stakeholders. The network that is formed between users eventually forms a community or society that consciously or will not bring up the values that exist in the community. Technology must be supported by electricity, the state of electricity in Central Tapanuli Regency is also adequate and can be utilized by other facilities.

\section{c. Economy}

With tourism of course, it will also have an impact on the community, one of which is the economic impact. At Pandan Beach there are also boat rentals and rubber boat rides (Banana boat) to get around Pandan Beach. Boat rental and banana boat is quite affordable so that it adds to the appeal of Pandan Beach tourist destinations. In addition to the availability of boat rentals and banana boats to play water at Pandan Beach there is also a seafood restaurant, culinary snacks typical of Tapanuli Tengah, and simple food stalls, there are also souvenir traders typical of the beach, namely shellfish can be used as accessories and displays for home. Souvenir sellers are also one of the conditions for the development of a tourist attraction and can develop the Pandan Beach tourist attraction area for the better. Pandan Beach destination area is one of the souvenir centers. Pandan Beach area also has hotels and lodging from the most expensive prices to the cheapest prices. The hotel that is directly adjacent to pandan beach is called PIA hotel. This hotel is one of the best hotels in Central Tapanuli Regency.

\section{d. Health}

Health facilities are very important in people's lives. Central Tapanuli regency has 1 Regional General Hospital (RSUD) and RSU is located in Pandan Subdistrict, and more fortunately the hospital is only 150 meters from pandan beach. In addition, in Pandan District there are also 2 health centers, 5 auxiliary health centers, and 3 clinics (Source: BPS Tapanuli Tengah).

\section{e. Social}

The population of Central Tapanuli consists of multi-ethnic tribes, namely coastal tribes, Batak, Minang, Jawa-Madura, Bugis, China, Aceh, Malay, Sundanese, and others, with the majority of Batak tribes. Preservation of noble values and nationality, harmony, security, order and tolerance in the spirit of gotong-royong that has been established and built so far makes Central Tapanuli more conducive and socially resilient society in responding to globalization with various changes that are so fast. The spirit of gotong royong continues to be built and improved in order to increase awareness, discipline, care and the spirit of togetherness of all levels of society with the spirit of Sahata Saoloan (Seiya Sekata) to strengthen the spirit of Bhineka Tunggal Ika. (source: central tapanuli bps) 
The five aspects above certainly decreased over the past 2 years due to the covid-19 pandemic that occurred globally, including North Sumatra Province and Central Tapanuli Regency. With the lockdown regulations and then continue on PSBB and PPKM, making the natural attractions of pandan beach deserted visitors. So as to make other things around it experience considerable losses, such as people losing their livelihoods (small / medium enterprises), and even up to entrepreneurs losing consumers (lodging and accommodation businesses). The covid-19 pandemic is very affecting their income, some even lose their jobs.

4.2. Suitability of Spatial Arrangement in the Regency to the Recovery and Development of Natural Attractions in Pandan Beach of Central Tapanuli Regency a. Distribution of District Facilities and Infrastructure

Table 1. District facilities and infrastructure

\begin{tabular}{lcc}
\hline \multicolumn{1}{c}{ Information } & Regency & Pandan District \\
\hline Number of restaurants / restaurants & 5 & 3 \\
Number of hotels / inns & 23 & 13 \\
Long road & $960,96 \mathrm{~km}$ & - \\
Communication: number of post offices & 7 & 1 \\
Phc & 21 & 2 \\
Hospital & 1 & 1 \\
\hline
\end{tabular}

Source: Central Tapanuli BPS 2020

\section{b. Distribution of Tourism Attractions}

The development of destination areas in Central Tapanuli Regency has been seen for a long time, because of its location in the highlands (hills) and lowlands (coast and sea). So that the government prioritizes development in natural tourism.

Table 2. Central Tapanuli Regency Attractions

\begin{tabular}{lcc}
\hline \multicolumn{1}{c}{ Tourist attraction } & Districts & $\begin{array}{c}\text { Distance from } \\
\text { Pandan Distric1 } \\
\text { (Kilometres) }\end{array}$ \\
\hline Sipitu-pitu Waterfall & Tukka & \pm 8 \\
Sihobuk Waterfall & Sarudkik & \pm 5 \\
Alobar Bair Waterfall & Tapian Nauli & $\pm 18,5$ \\
Golkar Waterfall & Tapian Nauli & \pm 25 \\
Hollywood Beach & Pandan & \\
Pandan Beach & Pandan & \\
Indah Pandan Beach & Pandan & \\
Indah Kalangan Beach & Pandan & \pm 1 \\
Muara Nauli Beach & Sorkam & \pm 45 \\
Binasi Beach & Sorkam Barat & \pm 40 \\
Indah Sibintang Beach & Sosorgadong & \pm 50 \\
Kualo Barangbang Beach & Sosorgadong & \pm 60 \\
Kade Tigo Beach & Barus & \pm 65 \\
Kahona Beach & Andam Dewi & \pm 95 \\
Sitiris tiris Beach & Andam Dewi & \pm 95 \\
\cline { 2 - 3 } & &
\end{tabular}




\begin{tabular}{lcc}
\hline Pulau Putri Beach & Tapian Nauli & \\
Mursala Island & Tapian Nauli & \\
Kalimantung Island & Tapian Nauli & \\
Papan Tinggi Grave & Barus Utara & \pm 80 \\
Mahligai Grave & Barus & \pm 80 \\
Zero Point Monument of Islam Nusantara & Barus & \pm 80 \\
Aek Simartolu & Sitahuis & \pm 18 \\
\hline
\end{tabular}

Source: Central Tapanuli BPS 2020

Based on table 2 above, central Tapanuli Regency has many attractions that can be used as a tourist attraction for tourists both from abroad and those from within the country. The tourism area in Central Tapanuli Regency is not only limited to the type of tourism that utilizes natural resources, but also utilizes history and culture. By looking at the facilities and infrastructure in Central Tapanuli Regency and looking at the number of tourist attractions that exist, it is concluded that there is the development of superior facilities and infrastructure in Pandan District which is the capital of Central Tapanuli Regency. Where pandan district has 4 tourist destinations that are strategically located (not far from the city). The most influential space functions due to the covid-19 pandemic are restaurants/ restaurants and inns / hotels.

\subsection{Priority of Handling Infrastructure and Spatial Planning Policy for Accelerating the Recovery and Development of Natural Attractions in Pandan Beach, Central Tapanuli Regency}

Economic losses from the cessation of tourism activities have implications for other aspects because although they do not get acceptance from tourism services but tourism management activities continue to run such as the maintenance of tourism facilities, the distribution of water and electricity dues, the application of employees both working and those who are housed and so on. This condition creates an imbalance between income and expenditure for tourism businesses, so it does not rule out the possibility for entrepreneurs who experience large losses, have the burden to restore tourism activities (Permana, 2020).

The recommendations of business actors in the recovery of tourism due to the covid19 pandemic consist of internal factors and external factors, considering that the COVID19 outbreak not only has an economic impact but has an organizational impact of losses, one of which is the non-realization of tourism business goals that have been set. In conducting tourism recovery internally, businesses can form an internal team to assess the impact and potential after the Covid-19 outbreak, this team will specifically compile various tourism recovery programs. First, efforts to recast the tourism business plan affected by the Covid-19 outbreak, this is based on the losses caused by the cessation of tourism business so that steps are needed to restore business, namely by re-planning the sustainability of the tourism business. The business starts from the data collection of which types of tourism businesses suffered many losses to what kind of business opportunities have the potential to return the tourism business to its original condition in a fast time and efficient cost.

Second, efforts to re-manage human resources, this is related to how effectively existing human resources are able to encourage the development of tourism businesses so that they can recover in a fast time. The existence of employees who are housed during the Covid-19 outbreak must also be used as input on whether the proportion of human resources in running tourism businesses has been managed effectively or needs reduction / addition to launch the recovery process of tourism business. 
Internal tourism recovery efforts for business actors must also be followed by external efforts, including communication and coordination with tourism stakeholders, especially the Central Tapanuli Regency Government, about the steps that must be taken to synergize tourism recovery efforts. The same important business is to draw up a joint work plan with stakeholders in the post-Covid-19 tourism recovery effort, such as proposing to the Central Tapanuli Regency Government about the forms of tourism recovery programs as part of a relaxation policy that can be given to tourism businesses so that through the tourism recovery program can accelerate the recovery of tourism business.

The last effort that must be taken by tourism business actors in order to restore tourism in Central Tapanuli Regency is to promote both directly to tourists such as providing discounts for tourist services and in the form of indirect promotions such as advertisements in print and electronic media about the advantages of the type of tourism that exists after the Covid-19 outbreak. The promotion is expected to increase tourism interest which is expected to bring many tourists to the city of Bandung and will directly have implications for the return of tourism conditions to the original conditions as before the Covid-19 outbreak.

\section{Conclusion}

1) The carrying capacity of central Tapanuli Regency infrastructure to the recovery and development of natural attractions on pandan beach, which already has infrastructure such as transportation, economy, health and social.

2) The suitability of spatial arrangements in the Regency to the recovery and development of natural attractions on pandan beach, namely when viewed from the distribution of facilities and infrastructure and the distribution of tourism attractions the most influential space functions due to the covid-19 pandemic are restaurants / restaurants and lodging / hotels.

3) Priority handling infrastructure and spatial arrangement policy for the acceleration of recovery and development of natural attractions on the pandan beaches of Central Tapanuli Regency, namely the economy. Whether it's a small/medium-sized business or a large scale.

\section{References}

Abdulhaji, Sulfi, and Ibn Sina Hi Yusuf. "The influence of attractions, accessibility and facilities on the image of the Big Tolire Lake tourist attraction in Ternate City." Humano: Research Journal 7.2 (2017): 134-148.

Amin, M et al. (2019). Marketing Communication Strategy To Improve Tourism Potential. Budapest International Research and Critics Institute-Journal (BIRCI-Journal). P. 160-166.

Bachry, John. "Analysis of Conflict in the Implementation of Regional Spatial Policy in Sustainable Tourism Development in the Rinjani-Lombok Geopark Area, West Nusa Tenggara Province By." Scientific Development Media 13.12 (2019): 1879-1894.

bpstapanulitengah.go.id

Kamil, Sitti Utami Rezkiawaty. "City branding as a tourism communication strategy in Central Buton Regency." Metacommunication: Journal of Communication Studies $2.1(2017)$. 
Nabila, Amira Dzatin, and Dyah Widiyastuti. "A Study of Attractions, Amenities and Accessibility for the Development of Umbul Ponggok Tourism in Klaten Regency." Indonesian Journal of Earth 7.3 (2018).

Najmi, N., and Nurmaida Amri. "Mossec Periodization in the Spatial Development of Archipelagic Tourism Destinations Areas on Batam Island." The Lost World 16 (2016).

Wahyono, Sharfina Bella Pahleva, and Suzanna Ratih Sari. "The Impact of Tourism on Settlement Spatial Planning." (2021). 